\title{
Net protein utilization determined by rat bioassay of a protein hydrolysate and a diet for children with phenylketonuria
}

\author{
BY ELISABETH KINDT ${ }^{1}$, HALVOR HOLM², SVERRE HALVORSEN ${ }^{3}$ \\ AND SVERRE O. LIE \\ ${ }^{1}$ Paediatric Research Institute, Rikshospitalet, Oslo, Norway \\ ${ }^{2}$ Institute for Nutrition Research, School of Medicine, University of Oslo, Norway \\ ${ }^{3}$ Department of Paediatrics, Ullevål Sykehus, University of Oslo, Norway
}

(Received 20 March 1984 - Accepted 29 March 1985)

1. In a previous study (Kindt et al. 1983, 1984) it was assumed that a protein hydrolysate, devoid of phenylalanine, together with intact protein as given to children with phenylketonuria (PKU), was equivalent to egg or milk protein. One group of children was given this 'PKU protein' in amounts corresponding to the Joint FAO/WHO ad hoc Expert Committee (1973) recommendations. The results indicated that the Joint FAO/WHO ad hoc Expert Committee (1973) recommended levels of protein intake were marginal.

2. The purpose of the present study was to evaluate whether the quality of the protein hydrolysate, together with intact protein ('PKU protein'), is equivalent to egg or milk protein. This was done using a rat bioassay. Four protein sources were used: (1) egg protein, (2) protein hydrolysate, (3) protein hydrolysate diluted with non-essential amino acids, (4) protein hydrolysate mixed with food proteins ('PKU protein'), comparable with the diet previously used (Kindt et al. 1983, 1984).

3. The results indicated that the 'PKU protein' was of very high quality: net protein utilization (NPU) $>90$. The protein hydrolysate alone and the protein hydrolysate diluted with non-essential amino acids gave a NPU $>80$.

4. The conclusion drawn from the present study is that the 'PKU protein', as used in the treatment of children with PKU, is equivalent to egg or milk protein. This supported the view that the Joint FAO/WHO ad hoc Expert Committee (1973) recommended levels of intake were marginal.

The best way to evaluate the quality of dietary protein is to perform a longitudinal study using human beings for whom the food is intended to be used. For adults, this type of study is costly and time-consuming. For children, this type of study is also impossible due to ethical reasons. Rat studies are therefore often recommended (Joint FAO/WHO ad hoc Expert Committee, 1973).

We have previously reported the results of a comparison of two groups of children with classical phenylketonuria (PKU; Tourian \& Sidbury, 1974) receiving diets differing only in the amount of protein (Kindt et al. 1983, 1984). The group with the higher intake (RDA group) received protein at a level based on the recommendations of the (US) Food and Nutrition Board $(1974,1980)$, that is from 1 to 3 years $1.8 \mathrm{~g} / \mathrm{kg}$ per $\mathrm{d}$. The group with the lower intake (FAO group) received protein at the level recommended by the Joint FAO/WHO ad hoc Expert Committee (1973), that is from 1 to 2 years $1.27 \mathrm{~g} / \mathrm{kg}$ per $\mathrm{d}$ and from 2-3 years $1 \cdot 19 \mathrm{~g} / \mathrm{kg}$ per $\mathrm{d}$. The protein source used was mainly derived from a protein hydrolysate but some milk, vegetables and fruit were added to the diet. This mixture of proteins ('PKU protein') was assumed to be equivalent to egg or milk protein which is a prerequisite for employing the Joint FAO/WHO ad hoc Expert Committee (1973) recommendations for protein intake. The non-optimal growth of some of the children in the previous study (Kindt et al. 1983, 1984) therefore indicated that the Joint FAO/WHO ad hoc Expert Committee (1973) recommended levels of intake were borderline and possibly too low. It was considered necessary, therefore, to evaluate whether the quality of the 'PKU protein' really is equivalent to that of egg or milk protein. This was done using a rat bioassay. Three different nitrogen sources, keeping the amount of $\mathrm{N}$ constant, were 
compared with the quality of egg protein. The results indicate that the quality of the 'PKU protein' is equivalent to egg protein. The results also show that the protein hydrolysate is of high quality and that the dilution of the hydrolysate with non-essential amino acids does not lower the protein quality.

\section{MATERIALS AND METHODS}

\section{The quality of protein}

The quality of protein is primarily determined by two factors: digestibility (eqn (1)) and utilization of the absorbed amino acids (eqn (2)):

$$
\begin{aligned}
& \text { absorbed } \mathrm{N}=\text { intake } \mathrm{N}-(\text { total faeces } \mathrm{N}-\text { metabolic faecal } \mathrm{N}), \\
& \text { retained } \mathrm{N}=\text { absorbed } \mathrm{N}-\text { (total urinary } \mathrm{N} \text {-endogenous urinary } \mathrm{N} \text { ). }
\end{aligned}
$$

The indices were true digestibility (TD), biological value (BV) and net protein utilization (NPU).

\section{Animals and housing}

The method was a slight modification of the method described by Eggum (1980). Groups of Wistar male rats $(n 6) 26 \mathrm{~d}$ of age, weighing from 75 to $78 \mathrm{~g}$ were used. The mean weight of each group varied by $0.5 \mathrm{~g}$ or less. The preliminary period lasted for $4 \mathrm{~d}$ and the experimental period for $5 \mathrm{~d}$. During the whole period the temperature was kept at $22 \pm 1 \cdot 0^{\circ}$ and the relative humidity at $60 \pm 5 \%$. Lighting was controlled by a $12 \mathrm{~h}$ light-dark cycle. During the whole period the animals were kept in individual plastic metabolism cages. Water was supplied ad lib. During the preliminary and experimental periods, $10.0 \mathrm{~g}$ dry diet were offered daily. Food not eaten during the experimental period was collected each day and weighed at the end of the $5 \mathrm{~d}$. Urine and faeces were collected separately for the $5 \mathrm{~d}$ experimental period.

\section{Diets}

In addition to four experimental groups, one group was employed for the determination of metabolic faecal $\mathrm{N}$ and endogenous urinary $\mathrm{N}$, and one group was given casein as a control group (Eggum, 1980).

The $\mathrm{N}$-free mixture (for adjusting the protein level) consisted of autoclaved potato starch, sucrose, cellulose, soya-bean oil and vitamins. The control group received $150 \mathrm{mg} \mathrm{N} / 10 \mathrm{~g}$ dry diet per rat per d (approximately $10 \%$ of energy from protein). This $\mathrm{N}$ was derived from casein fortified with $10 \mathrm{~g}$ DL-methionine $/ \mathrm{kg}$. The quality of this protein source should give a standardized NPU $\left(\mathrm{NPU}_{\mathrm{st}}\right)$ of approximately 88 (Eggum, 1980).

The protein hydrolysate used was Albumaid XP (Scientific Hospitals Supplies Ltd, Liverpool, UK). The amino acids in this formula were derived from ox serum from which phenylalanine was removed. In the present study, phenylalanine was added to the Albumaid XP by the manufacturer in amounts equivalent to that in cow's milk (FAO, 1970). The composition of this particular batch of Albumaid XP with added phenylalanine (Albumaid $\mathrm{P}+$; Table 1) was almost identical to the composition given in the manufacturer's product information, except that histidine was present in larger amounts. The essential amino acids in Albumaid $\mathbf{P}+$, compared with the suggested pattern of requirement for infants (Joint FAO/WHO ad hoc Expert Committee, 1973), were present in excess from 24 to above $100 \%$. Albumaid $\mathrm{P}+$ contained $(/ \mathrm{kg}) 410.9 \mathrm{~g}$ amino acids, $500 \mathrm{~g}$ modified starch, vitamins, minerals and trace elements.

The diet of the four experimental groups contained $97.5 \mathrm{mg} \mathrm{N} / 10 \mathrm{~g}$ dry diet per $\mathrm{d}, 6.5 \%$ of energy from protein (Table 2), to resemble the low-protein concentration in diets employed for the FAO group (Kindt et al. 1983, 1984). In group 1, the N was derived from egg protein (defatted whole egg). In group 2, the $\mathrm{N}$ was derived entirely from Albumaid 
Table 1. The amino acid pattern of Albumaid P+*

\begin{tabular}{|c|c|c|}
\hline Amino acids & $\begin{array}{l}\text { Albumaid } \mathrm{P}+ \\
\text { (mg/g protein) }\end{array}$ & $\begin{array}{l}\text { Suggested pattern } \\
\text { of requirement } \\
\text { for infants } \dagger \\
\text { (mg/g protein) }\end{array}$ \\
\hline Histidine & 80 & 14 \\
\hline Isoleucine & 56 & 35 \\
\hline Leucine & 99 & 80 \\
\hline Lysine & 94 & 52 \\
\hline Methionine & 28 & \\
\hline Cystine & 48 & \\
\hline Sum of sulphur aa & 76 & 29 \\
\hline Phenylalanine & 54 & \\
\hline Tyrosine & 93 & \\
\hline Sum of aromatic aa & 147 & 63 \\
\hline Threonine & 75 & 44 \\
\hline Tryptophan & 11 & 8.5 \\
\hline Valine & 73 & 47 \\
\hline
\end{tabular}

aa, Amino acids.

* Scientific Hospitals Supplies Ltd, Liverpool, UK.

$\dagger$ Joint FAO/WHO ad hoc Expert Committee (1973).

Table 2. Nitrogen sources and contribution $(\mathrm{mg} N / \mathrm{g}$ dry diet per rat per $d)$ in the four experimental diets

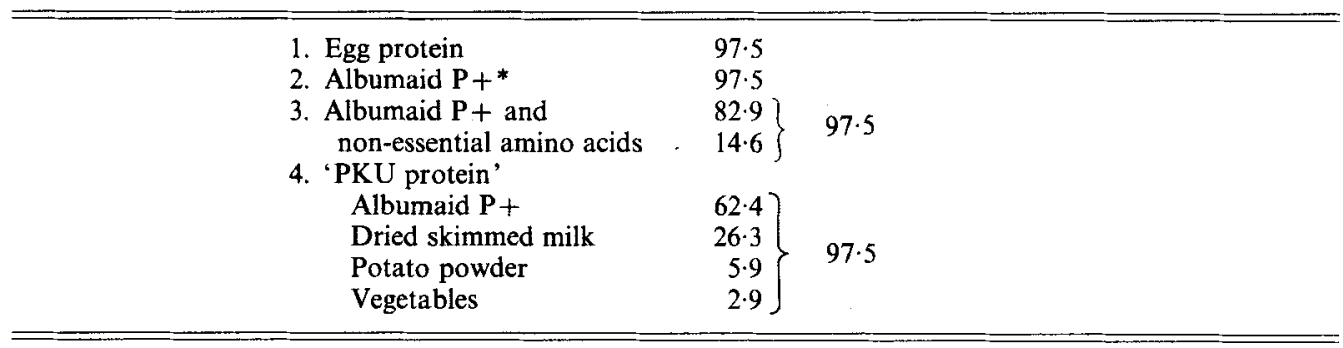

PKU, phenylketonuria.

* Scientific Hospitals Supplies Ltd, Liverpool, UK.

$\mathrm{P}+$. In group 3, 85\% of the $\mathrm{N}$ was derived from Albumaid $\mathrm{P}+$ and $15 \%$ of the $\mathrm{N}$ from non-essential amino acids. The amino acid pattern of these amino acids was the same as in Albumaid $\mathrm{P}+$. In group 4, 64\% of the $\mathrm{N}$ was derived from Albumaid $\mathrm{P}+, 27 \%$ from dried skimmed milk, $6 \%$ from potatoes and $3 \%$ from vegetables.

\section{RESULTS}

The NPU $\mathrm{St}_{\mathrm{st}}$ of the casein fortified with $10 \mathrm{~g}$ DL-methionine $/ \mathrm{kg}$ was $91.6(84 \cdot 3-96 \cdot 2)$ (median and range) indicating correct experimental conditions. The metabolic faecal $\mathrm{N}$ and the endogenous urinary $\mathrm{N}$ were $2.08 \mathrm{mg} / \mathrm{g}$ dry diet and 56.3 (SD 2.1 ) mg/5 d respectively. Table 3 shows the $\mathrm{N}$ balance and the weight gain of the four experimental groups. It is seen that on the basis of BV and NPU, 'PKU protein' had a protein quality as good as that of egg protein. These values were statistically significantly higher than those of the two amino acid mixtures (groups 2 and $3 ; P<0.05$ ), using a one-sided Wilcoxon range test. No reduction in quality of Albumaid $\mathrm{P}+$ was observed when $15 \% \mathrm{~N}$ from Albumaid $\mathrm{P}+$ was replaced with only non-essential amino acids (group 3 ). 
Table 3. Nitrogen balance and weight gain of rats given the four experimental diets* (Mean values and standard deviations for six rats per group)

\begin{tabular}{|c|c|c|c|c|c|c|c|c|c|c|}
\hline \multirow[b]{3}{*}{ Dietary group } & \multicolumn{4}{|c|}{ Dietary intake } & \multicolumn{4}{|c|}{ Dietary output } & & \\
\hline & \multicolumn{2}{|c|}{ Dry wt $(g / 5 \mathrm{~d})$} & \multicolumn{2}{|c|}{$\mathrm{N}(\mathrm{mg} / 5 \mathrm{~d})$} & \multicolumn{2}{|c|}{$\begin{array}{l}\text { Faecal N } \\
(\mathrm{mg} / 5 \mathrm{~d})\end{array}$} & \multicolumn{2}{|c|}{$\begin{array}{l}\text { Urine } \mathrm{N} \\
(\mathrm{mg} / 5 \mathrm{~d})\end{array}$} & \multicolumn{2}{|c|}{$\begin{array}{l}\text { Weight gain } \\
\quad(\mathrm{g} / 9 \mathrm{~d})\end{array}$} \\
\hline & Mean & SD & Mean & SD & Mean & SD & Mean & SD & Mean & SD \\
\hline 1. Egg protein & 50.0 & 0.0 & $506 \cdot 5$ & 0.0 & $130 \cdot 5$ & $8 \cdot 7$ & $70 \cdot 1$ & $8 \cdot 6$ & $12 \cdot 0$ & $3 \cdot 0$ \\
\hline 2. Albumaid $\mathbf{P}+\dagger$ & $46 \cdot 3$ & $2 \cdot 4$ & $462 \cdot 5$ & $24 \cdot 3$ & $83 \cdot 1$ & $10 \cdot 5$ & $142 \cdot 1$ & 9.4 & 12.5 & 2.8 \\
\hline $\begin{array}{l}\text { 3. Albumaid } P+\text { with } \\
\text { non-essential amino acids }\end{array}$ & $49 \cdot 7$ & $1 \cdot 1$ & $502 \cdot 0$ & $11 \cdot 5$ & $94 \cdot 2$ & $7 \cdot 4$ & $143 \cdot 5$ & $9 \cdot 0$ & $14 \cdot 4$ & 1.8 \\
\hline 4. PKU protein & $49 \cdot 5$ & $0 \cdot 4$ & 456.5 & 1.8 & $116 \cdot 1$ & $22 \cdot 1$ & 69.8 & $7 \cdot 3$ & $11 \cdot 2$ & $3 \cdot 4$ \\
\hline
\end{tabular}

PKU, phenylketonuria.

* For details, see Tables 1 and 2.

$\dagger$ Scientific Hospitals Supplies Ltd, Liverpool, UK.

Table 4. The protein quality of the experimental diets given to rats

(Median values and ranges)

\begin{tabular}{|c|c|c|c|c|c|c|}
\hline \multirow[b]{2}{*}{ Dietary group $\dagger$} & \multicolumn{2}{|c|}{$\begin{array}{l}\text { True digestibility } \\
\text { (TD) }\end{array}$} & \multicolumn{2}{|c|}{$\begin{array}{l}\text { Biological value } \\
\text { (BV) }\end{array}$} & \multicolumn{2}{|c|}{$\begin{array}{c}\text { Net protein } \\
\text { utilization (NPU) }\end{array}$} \\
\hline & Median & Range & Median & Range & Median & Range \\
\hline 1. Egg protein & $95 \cdot 0$ & $93 \cdot 2-97 \cdot 6$ & $95 \cdot 0$ & $94 \cdot 9-98 \cdot 1$ & $91 \cdot 6$ & $88 \cdot 4-93 \cdot 5$ \\
\hline 2. Albumaid $P+\ddagger$ & $102 \cdot 0$ & $100 \cdot 8-107 \cdot 8$ & $81 \cdot 4$ & $80 \cdot 7-85 \cdot 7$ & $83 \cdot 2$ & $81 \cdot 5-88 \cdot 1$ \\
\hline $\begin{array}{l}\text { 3. Albumaid } P+\text { with } \\
\text { non-essential amino acids }\end{array}$ & $102 \cdot 5$ & $98 \cdot 0-103 \cdot 0$ & $83 \cdot 0$ & $80 \cdot 9-85 \cdot 3$ & $81 \cdot 6$ & $80 \cdot 8-85 \cdot 3$ \\
\hline 4. 'PKU protein' & $95 \cdot 3$ & $92 \cdot 7-103 \cdot 8$ & $97 \cdot 2$ & $94 \cdot 2-99 \cdot 2$ & $93 \cdot 5$ & $88 \cdot 4-101 \cdot$ \\
\hline
\end{tabular}

PKU, phenylketonuria; $\mathrm{TD}=(\mathrm{N}$ absorbed $/ \mathrm{N}$ intake $) \times 100 ; \mathrm{BV}=(\mathrm{N}$ retained $/ \mathrm{N}$ absorbed $) \times 100 ; \mathrm{NPU}=(\mathrm{N}$ retained $/ \mathrm{N}$ intake) $\times 100$.

Statistically significant differences $(P<0.05)$ using one-sided Wilcoxon range test were obtained between the following groups: TD, 2 v. $1 ; 3$ v. $1 ; \mathrm{BV}$ and NPU, 2 v. $1 ; 3$ v. $1 ; 4$ v. $2 ; 4$ v. 3 .

$\dagger$ For details of diets, see Tables 1 and 2.

\$ Scientific Hospitals Supplies Ltd, Liverpool, UK.

\section{DISCUSSION}

We have previously reported the results of a comparison of two groups of PKU children receiving diets differing only in the amount of protein (Kindt et al. 1983, 1984). The RDA group received protein at a level based on that recommended by the (US) Food and Nutrition Board $(1974,1980)$. The FAO group received protein at a level recommended by the Joint FAO/WHO ad hoc Expert Committee (1973), which is approximately $70 \%$ of the levels of protein recommended by the (US) Food and Nutrition Board (1974, 1980). The results led us to suspect that the FAO group had received a marginal and, possibly, too low protein intake. Whether the Joint FAO/WHO ad hoc Expert Committee (1973) recommendations really are marginal depends on the assumption that the mixture of protein hydrolysate and intact protein, 64 and $36 \%$ respectively, as given to the FAO children, really was of sufficiently high quality, i.e. equivalent to egg or milk protein. 
The Joint FAO/WHO ad hoc Expert Committee (1973) recommend that the amount of protein in a diet should be adjusted according to quality, determined by standardized rat bioassays, to achieve a safe level of protein intake.

Albumaid XP and Albumaid P+ are mixtures of amino acids. Whether amino acids are equally well utilized as intact protein in man is, as far as we know, not yet established. There seems to be general agreement, at least for rats (Sugahara et al. 1969; Itoh et al. 1973; Forsum, 1975; Forsum \& Hambraeus, 1978), that if there is any difference, intact protein is best utilized. The reason for this is that even if amino acids are better absorbed from the intestinal tract, the loss in the urine as urea is greater, resulting in a greater loss of $\mathrm{N}$. In man (Anderson et al. 1969), no difference was found in $\mathrm{N}$ balance when casein or eighteen L-amino acids simulating casein were used. In a similar study using man, Smith et al. (1982) showed that even if amino acids are efficiently absorbed from the intestinal tract, the $\mathrm{N}$ loss as urea is greater than when intact protein is used, resulting in poorer $\mathbf{N}$ retention. Thus it seemed justified to extrapolate results using only amino acids, or amino acids together with intact protein, from rats to humans.

Instead of $150 \mathrm{mg}, 97.5 \mathrm{mg} \mathrm{N} / 10 \mathrm{~g}$ dry diet per rat per $\mathrm{d}$ were used in the four experimental groups, representing $6.5 \%$ instead of $10 \%$ energy from protein. This was done because the FAO group of children received protein at about $6.5 \%$ of energy intake at the age of 15 months, and we suspected the Joint FAO/WHO ad hoc Expert Committee (1973) recommendations to be marginal from the age of 12 months. Of the $\mathrm{N}$ from Albumaid $\mathrm{P}+$ and from intact protein, 64 and $36 \%$ respectively were also used for the same reason.

Our results are in agreement with other studies using rats or humans where only amino acids or only intact protein were given. The 'PKU protein' behaved like intact protein with a very small loss of $\mathrm{N}$ in the urine resulting in a protein quality similar to that of egg protein. Thus the assumption that protein hydrolysate and intact protein as given to the FAO children is equivalent to egg or milk protein is strengthened, and accordingly we still suspect the Joint FAO/WHO ad hoc Expert Committee (1973) 'safe levels of intake of egg or milk protein' to be marginal.

This research was supported by funds from the Norwegian Council for Research on Mental Retardation.

\section{REFERENCES}

Anderson, H. L., Heindel, M. B. \& Linkswiler, H. (1969). Journal of Nutrition 99, 82-90.

Eggum, B. O. (1980). In Nutritional Evaluation of Protein Foods, p. 108 [P. L. Pellett and V. R. Young editors]. Tokyo: United Nations University.

FAO (1970). Amino Acid Content of Food and Biological Data on Proteins. Rome: Food and Agriculture Organization.

Food and Nutrition Board (1974). Recommended Daily Allowances, 8th ed. Washington, DC: National Research Council/National Academy of Sciences.

Food and Nutrition Board (1980). Recommended Daily Allowances, 9th ed. Washington DC: National Research Council/National Academy of Sciences.

Forsum, E. (1975). Nutrition Reports International 11, 419-428.

Forsum, E. \& Hambraeus, L. (1978). Journal of Nutrition 108, 1518-1526.

Itoh, H., Kishi, T. \& Chibata, I. (1973). Journal of Nutrition 103, 1709-1715.

Joint FAO/WHO ad hoc Expert Committee (1973). Energy and Protein Requirements. Technical Report Series no. 522. Geneva: World Health Organization.

Kindt, W., Motzfeldt, K., Halvorsen, S. \& Lie, S. O. (1983). American Journal of Clinical Nutrition 37, $778-785$.

Kindt, E., Motzfeldt, K., Halvorsen, S. \& Lie, S. O. (1984). British Journal of Nutrition 51, 435-442.

Smith, J. L., Arteage, C. \& Heymsfield, S. B. (1982). New England Journal of Medicine 306, 1013-1018.

Sugahara, M., Baker, H. D., Harmon, B. G. \& Jensen, A. H. (1969). Journal of Nutrition 98, 344-350.

Tourian, A. Y. \& Sidbury, J. B. (1974). In The Metabolic Basis of Inherited Disease, p. 240 [J. B. Stanbury, J. G. Syngarden and D. S. Fredrickson, editors]. New York, McGraw-Hill Book Co. 